\title{
Problems of Diversion System Application in The Case of Children as Actorscrime of Narcotics are Based Restorative Justice
}

\author{
Frans Simangunsong ${ }^{1 *}$ \\ ${ }^{1}$ Faculty of Law, Sultan Agung Islamic University, Semarang, Indonesia
}

\begin{abstract}
The diversion process is carried out through deliberations involving children and their parents, community counselors, and professional social workers, which is carried out with a restorative justice approach. In the paper, the author puts legal concepts incorporation are positive norms in the national legal system and concepts are symbolic meanings manifestations on social behavior as visible interactions. This study uses a research method with a juridical empiric research approach, directed to obtain secondary data and primary data sourced from library materials and from legislation implementation. Law No.11/2012 concerning the Children Criminal Justice System has considered aspects in the Criminal Law Politics, especially the formation of criminal legislation with regard to aspects of social defense and social welfare. The diversion policy is in line with the values of Indonesian society's legal culture through Law No.11/2012 functions as a social engineering tool. Law No.35/2009 concerning Narcotics, explains generally about criminal sanctions for narcotics intermediaries but does not specifically regulate criminal sanctions for children who are narcotics couriers. The diversion process should not be confined to the limit of imprisonment under 7 years. Since the International Law principles, where diversion must prioritize the best children interests in order to achieve Restorative Justice for children.
\end{abstract}

\section{Introduction}

\subsection{Background}

Law in its development is not only used to regulate behavior that already exists in society and maintain existing patterns of habits but more than that, the law leads to its use as a means. To carry out the goals that have been chosen and determined so that they can be realized in the community, there are several means needed. One sufficient means is the law with various forms of existing legislation [1]. The problem of crime is one of the social problems that is always interesting and demands serious attention from time to time. Even more. according to general assumptions and several observations and research of various parties, there is a tendency to increase in certain forms and types of crime, both in quality and quantity [2].

Drugs have become a serious problem for this nation. These illicit goods undermine

*Corresponding author: frans@unsa.ac.id 
anyone. People's representatives, judges, artists, pilots, students, workers, even housewives do not escape drug trafficking. In terms of age, drugs also never choose their victims, ranging from children, teenagers, adults, even to the elderly. Indonesia is a 'paradise' of drug trafficking. Why not, if judging from the circulation of drugs in the world, our country ranks third as the largest drug market in the world.

The more sophisticated advances in communication technology and transportation technology make drug trafficking transactions easier. Transactions can be done through internet media that are subject to packages, so that sellers and buyers do not need to do faceto-face which is more easily known by the police. Besides that, smuggled drugs are packaged in various ways to trick security officers. The strong reason that makes Indonesia experience a crisis in drug trafficking is in fact, 60-70 percent of narcotics circulating in Indonesia come from abroad, only $30-40$ percent of narcotics. local origin, mainly marijuana. This means that Indonesia has indeed lost its borders which makes it easier for foreign countries to export illegal drugs.

In order to smuggle drugs into Indonesia, in fact the syndicates will use various methods, including the mode by utilizing underage children as drug couriers. Therefore the investigators need to be aware of the possibility of suspected criminal cases of narcotics that are underage children. Law Number 11 of 2012 concerning Child Criminal Justice System (SPPA) can conflict with Law Number 35 of 2009 concerning Narcotics. This is because the SPPA Law puts forward the element of diversion or transfer of criminal penalties at the level of examination, prosecution and trial for the suspect. "It means that if a drug suspect is a minor then it is possible that he will get a different sanction, because the SPPA Act applies to him, a 14-year-old narcotics criminal who acts as a drug courier, his case is treated with diversion. Darmawel said that such cases need to be watched out by investigators because it is possible to become a new mode used by drug syndicates. "Generally, couriers are always reasonable because they don't know anything. Investigators need to ensure that the child who is a drug courier is aware of his actions or is indeed used by a syndicate [3]. The criminal threat for children who are narcotics couriers is half of the criminal threats contained in the Narcotics Law. The international narcotics network has a new mode, which involves minors as supplier couriers.

\subsection{Problems}

1. What are the problems with the application of the diversion system in child cases as perpetrators of narcotics crimes based on restorative justice?

2. What are the efforts to overcome the problem of the application of the diversion system in child cases as perpetrators of narcotics crime based on restorative justice?

\section{Research Methods}

This research uses a research method with a juridisempiris research approach which is directed to obtain secondary data and primary data sourced from library materials and from the implementation of legislation. 


\section{Discussion}

\subsection{Problems in The Application of Diversion Systems in Cases of Children as Perpetrators of Narcotics-Based Restorative Crime.}

Limitations of the mention between children and adults can be distinguished from the age of a child. Because with the age of a person biologically and psychologically he can be categorized as children or not, although there are certain things that age limits cannot be used as a benchmark whether a person can be said to be lawful or not. However, in general the age limit of a person will make him obtain rights and perform certain obligations.

In the context of legal accountability, especially in criminal law, the age limit becomes very important. This is considered as a benchmark whether a person is considered by the law to be liable or not. A criminal act committed by an underage child who has not been able to clearly distinguish the consequences of his criminal act is clearly a situation of doubtful ability/awareness that he is committing a criminal act. This happens because children both psychologically and biologically have not been able to maintain their responsibility awareness.

Juridically, the laws and regulations in Indonesia provide different restrictions on the understanding of children. The most basic principle that distinguishes a child from an adult is age and legal action (ever married) before adulthood. Some laws provide different restrictions on the age limit of children so that their rights and obligations are relatively different.

In the realm of criminal law the child's age limit becomes an important matter, because it will affect the responsibilities that will be faced by the child. Therefore, the age limit for criminal responsibility for children is very relevant.

Based on data from the Directorate of Narcotics Narcotics Crime Criminal Investigation which is processed from cases handled by all Regional Police (Polda) and the Directorate of Drug Crime in 2015 the number of drug suspects is less than the age of 15 (fifteen) years amounting to 69 (sixty nine) people In 2016, it increased to 114 (one hundred and fourteen) people, in 2017 until July 2017 there were 67 (six hundred and seven) people. Drug suspects aged 16 (sixteen) - 19 (nineteen) in 2015 were 2117 (two thousand one hundred and seventeen) people. In 2016 there were 2047 (two thousand forty seven) people, until July 2017 there were 1521 (one thousand five hundred and twenty one) people. Based on the type of work in 2015 there were 855 (eight hundred fifty five) students, and 932 (nine hundred thirty two) students became drug suspects out of a total of 50.178 (fifty thousand one hundred and seventy eight) cases. In 2016 there were 1075 (one thousand seventy five) students and 1276 (one thousand two hundred seventy six) students became suspects of a total of 60,387 (sixty thousand three hundred eighty seven) cases. Until July 2017 there were 795 (seven hundred ninety five) students and 656 (six hundred fifty six) students from a total of 36193 193 (thirty six hundred ninety three) cases [4].

The findings of the Indonesian Child Protection Commission, of about 87 million Indonesian children, around 5.9 million of them are drug addicts. He also said there were about 72 international drug networks that entered Indonesia [5].

The policies currently applied in the effort to control children as drug couriers include the following:

Law Number 35 of 2009 concerning Narcotics

For intermediaries in narcotics transactions of class I, the perpetrators are stipulated in the provisions:

Article 114 paragraph (1) Law Number 35 of 2009 concerning Narcotics:

"Anyone who without rights or against the law offers to be sold, sold, bought, received, 
become an intermediary in buying and selling, exchanging, or handing Narcotics Class I, sentenced to imprisonment for live or imprisonment for a minimum of 5 (five) years and a maximum of 20 (twenty) years and a fine of at least Rp. 1,000,000,000.00 (one billion rupiah) and a maximum of Rp. 10,000,000,000.00 (ten billion rupiahs)."

In Law Number 35 of 2009 concerning Narcotics("Narcotics Law") there are a number of criminal sanctions for people who become brokers/intermediaries in the transaction/sale of narcotics. These sanctions vary depending on the type of narcotics, their weight, and their form (whether they are still in the form of plants or narcotics ready for use).

A person who commits a crime related to drugs will face the state through his law enforcement apparatus based on Law Number 35 of 2009 concerning Narcotics and Law Number 5 of 1997 concerning Psychotropics, including children. Children who are exposed to criminal acts because they are perpetrators of drug abuse will also be processed through the same laws and regulations even though the trial process is different from adults. This relates to the special protection given to children by the state as mandated in Article 59 paragraph (1) and paragraph (2) of Law Number 35 of 2014 concerning Amendments to Law Number 23 of 2002 concerning Child Protection, namely the government, regional government and other state institutions have the obligation and responsibility to provide special protection to children, including children who are dealing with the law; and victims of abuse of narcotics, alcohol, psychotropic substances and other addictive substances.

\subsection{Efforts to Overcome the Problem of Applying the Diversion System lin Child Cases as Narcotics-Based Criminal Acts of Restorative Justice}

A child becomes evil or is well influenced by the community environment. When there is a decline in the function of social control institutions in the community, a child can lead to deviant behavior. Crime or criminal act is one form of deviant behavior that is not separated from the community [6].

Today many criminal acts that do it are children. Because someone who is categorized as a child of his thoughts is still unstable, still in desperate need of his parents' attention and guidance. The transition from childhood to adolescence is usually children experience anxiety in themselves. Like talking harshly, and sensitive to pain, and want to always be free with the aim of wanting to be considered as an adult [7].

The National Narcotics Agency (BNN) identified 68 (sixty eight) new types of drugs throughout 2017, most drugs were created to target children [8].

Children who commit criminal acts of drug abuse become one of the problems that have not been maximized. This is because the handling of children usually refers to the Law on the Criminal Justice System of Children, but often conflicts with Law number 35 of 2009 concerning Narcotics.

Children are considered vulnerable to being used as drug couriers by dealers. Addiction effects are used as weapons to use them. As many as 22 (twenty two) cases of children as drug couriers were reported to the Indonesian Child Protection Commission (KPAI) in 2017, 46 (forty six) children were victims of drug abuse [9].

Mode of giving drugs to children in various ways given free of charge. Furthermore, if the child has started to become addicted, the dealer then sells it. Or drug dealers use children to become couriers in return for free drugs to use. Children are given new types of narcotics that can be mixed into food, drinks, or other items. So that it is unknown that there is a drug content.

Actions that can be handed down to the child nakalialah return to parents, guardians or foster parents, submit to the state to attend education, coaching and work training or submit to the social department, or socio-community organizations engaged in education, coaching 
work training, besides in paragraph 2 it is said that the action in paragraph 1 can be accompanied by reprimand and additional conditions determined by the judge [10].

Criminal threats in the provisions of Article 127 in Law No.35 of 2009 concerning Narcotics (Narcotics Law) only apply to people who are adults. Whereas if there are minors who violate the provisions of the article to be sanctioned, the judge must also be guided by the provisions of Law No.11 of 2012 concerning the Criminal Justice System of the Child (Law on the Criminal Justice System of the Child) for granting types and periods of sanctions against the child. This is a consequence of the existence of the principle of lex specialis derogate lex generalis (the principle of legal interpretation which states that the law which is specific to the exclusion of general law) [11].

The principle of lex specialis derogate lex generalis is related to this crime, according to Sahardjo's opinion, the coaching system which was initially prison in nature changed to a coaching system. This understanding is also linear with the opinion of Bismar Siregar, that the role of the Judge in giving sanctions is not only to punish, but to direct the violator in the development of legal awareness [12].

Interpretation of these opinions, as well as the purpose of imprisonment regulated by Law No. 11 of 2012 concerning the Criminal Justice System of Children, the child who is sentenced to imprisonment is obliged to be placed in a special child development institution (LPKA), because this particular institution is lex specialis so that the child in undergoing the sentence matches the child's best interests in the process of growth. . In Act No. 3 of 1997 concerning Juvenile Courts, does not explicitly regulate the purpose of prosecution, but generally can be seen in the consideration. The aim to be achieved is to protect efforts in order to ensure the growth, development of physical, mental, and social as a whole, harmonious, harmonious and balanced. In addition, the explanation also explained that with the issuance of the Law on Juvenile Courts, it was intended to better protect and protect children in order to meet their long future. It is also intended to provide opportunities for children so that through guidance will be obtained their identity to be independent, responsible, and useful for themselves, their families, society, nation and state [13].

Theoretically, the tendency of judges to always impose imprisonment on children can be questioned is that the criminal, including imprisonment, is basically just a tool, namely a tool to achieve the goal of punishment. If the use of the tool cannot fulfill the intended purpose, then there is no reason to keep using the tool. In various theories there is an understanding, that the imprisonment as a tool to achieve the purpose of prosecution is still debated its effectiveness. That is, there is no guarantee that if the perpetrator of a crime is ultimately sentenced to imprisonment, he will automatically become a good and law-abiding member of the community. It is precisely what is often known is that the imprisonment has a negative impact which is very detrimental to the convict, especially the convicted child [14].

In treatment theory (theory of coaching/care). Treatment as a goal of punishment is put forward by a positive flow that argues that punishment is very appropriate to be directed to the perpetrator of the crime, not to his actions. But the punishment is intended by this sect to provide treatment measures (treatment) and repair (rehabilitation) to the perpetrators of crime as a substitute for punishment. This flow is based on determinism which states that a person commits a crime not based on his will because humans do not have free will and are limited by various factors both personal character, biological factors, and environmental factors [15].

In addition, the judge's decision can be made based on the Regulation of the Head of the National Narcotics Agency (Perka BNN) No. 11 of 2014 concerning Procedures for Handling Suspects and/or Defendants of Narcotics Addicts and Victims of Narcotics Abuse into Rehabilitation Institutions is by requesting an assessment with the recommendations of the Integrated Assessment Team established in each province and district/city. Likewise in Article 60 paragraph (3) of Law No. 11 of 2012 concerning the Criminal Justice System of the Child stated that the Judge is obliged to consider a social research report from the 
Community Guidance before making a case decision. One important element in juvenile justice is the Probation Officer in Indonesia carried out by BISPA (Correctional Guidance and Child Alleviation) which is tasked with investigating the social and cultural background of a child to commit a crime [16].

Law Number 35 of 2014 concerning Amendments to Law Number 23 of 2002 concerning Child Protection, regulates Special Protection for Children dealing with the law as referred to in Article 59 paragraph (2) letter b. This Special Protection is a protection of children's rights that must be protected as described in article 59A.

Under the Child Protection Act, children who are involved in narcotics crimes must be considered victims and not perpetrators because of their ignorance and lack of guidance from parents and the government in terms of legal consequences of drug abuse.

\section{Conclusion}

1. Accommodating diversion policy in Law Number 11 of 2012 concerning the Criminal Justice System of the Child has taken into account and considers aspects of Criminal Law Politics, especially the establishment of criminal legislation with regard to aspects of social defense and social welfare. The diversion policy is in line with the values of Indonesian society's legal culture, in addition to the harmony of diversionary ideas and the values of Indonesian people's local wisdom shows that diversion through Law No. 11 of 2012 functions as a tool of social engineering. Law Number 35 of 2009 concerning Narcotics, explains generally about criminal sanctions for narcotics intermediaries but does not specifically regulate criminal sanctions for children who are narcotics couriers. But basically the perpetrators of narcotics circulation involving children as narcotics couriers remain charged with the articles as stipulated in the Narcotics Act but do not override the special provisions stipulated in Law Number 11 of 2012 concerning the Criminal Justice System of Children.

2. Diversion can only be carried out for acts of imprisonment whose prison sentence is under 7 (seven) years. The diversion process should not be confined to the limit of imprisonment under 7 (seven) years. Because in principle in accordance with the principles of International Law, where diversion must prioritize the best interests of children in order to achieve Restorative Justice for children.

\section{Suggestion}

1. The need for revision of the Narcotics Act provisions on rehabilitation of child narcotics users;

2. The need for curriculums for drug use in schools;

3. Parents to educate their children against the dangers of drugs, so they do not become a market regeneration for the Bandar

\section{References}

1. B. Sunggono. Hukum dan Kebijaksanaan Publik, (Sinar Grafika, Jakarta, 1994)

2. M. K. Darmawan, Strategi Pencegahan Kejahatan, (Citra Aditya Bakti, Bandung, 1994)

3. https://www.pressreader.com/indonesia/kompas/20170930/281496456481972 accessed on 14 August 2018

4. B. Siregar, Bunga Rampai Karangan Tersebar, (Rajawali, Jakarta 1999)

5. https://hukum.tempo.co/read/1070157/merevisi-uu-narkotika accessed on 14 August 2018

6. M. Gultom, Perlindungan Hukum Terhadap Anak, (Sinar Grafika, Bandung, 2010)

7. W. Soetodjo, Hukum Perlindungan Anak, (Refika Aditama, Bandung, 2006) 
8. https://www.era.id/read/M9UONM-wacana-revisi-uu-narkotika-untuk-lindungi-anak accessed on 15 August 2018

9. http://news.metrotvnews.com/hukum/nN9D9erK-kpai-anak-anak-rentan-dijadikan-kurirnarkoba accessed on 15 August 2018

10. Ibid, p. 189

11. K. Adi, Diversi Tindak Pidana Narkotika Anak, p. 23. (Setara Press, Malang, 2015)

12. B. Siregar, Bunga Rampai Karangan Tersebar, p. 1. (Rajawali, Jakarta, 1989)

13. N. Samba, Pembaharuan Sistem Peradilan Anak di Indonesia, p. 27 (Graha Ilmu, Yogyakarta, 2010)

14. Kusno Adi, Op.Cit, Hal. 89

15. K. Adi, Diversi Tindak Pidana Narkotika Anak, (Setara Press, Malang, 2015)

16. Marlina, Hukum Penitensiere, (PT RefikaAditama, Bandung, 2011)

17. Sunaryo, Perlindungan Hukum atas Hak Asasi Manusia bagi Anak dalam Proses Peralihan Pidana, JDH, (2002)

18. N. Sambas. Pembaharuan Sistem PeradilanAnak di Indonesia, (Graha Ilmu, Yogyakarta, 2010) 